\title{
THE DIVISION OF LEGAL LABOR IN RUAL HAITI*
}

\author{
By PNina Lahav
}

\section{Introduction}

This paper explores the institutional facilities available to Haitian peasants for the settlement of their disputes. More specifically, it compares the institution of the Chef de Section - the lowest administrative appointee in the Haitian countryside and the Justice of the Peace - the lowest ranking judicial institution provided by the Haitian legal system. The paper further advances the hypothesis that at the present time there is a shift in the division of labor between the two institutions, in favor of the Justice of the Peace, and that this shift may be attributed to processes of social differentiation currently detectable in rural Haiti' ${ }^{1}$.

Little research has been done on rural life in Haiti in general, and its legal culture in particular. In this respect, this paper should be regarded only as an introductory invitation to more elaborate and extensive research of Haitian remedy agents. However, the importance of exploring the division of legal labor in rural Haiti goes beyond this contribution to knowledge. Haiti is a fascinating melange of European, African and American-Indian cultures. After the bloody revolution of 1804, in which Haiti gained its sovereignty, French Law was dominant in the newly organized legal system (Jean-Jacques, 1933). Yet the Haitian case was distinctly different from other cases of indigenous reception of foreign law, for the foreign legal system was not brought into an already existing and established indigenous legal culture (Collier, in press; Galanter, 1972), but into a recently liberated slave society, struggling to form its own culture. The Chef de Section and the Justice of the Peace were developed and institutionalized together, representing the mixture of distinctive cultural elements in the Haitian legal culture, a mixture characteristic of most other aspects of Haitian social life (Mintz, 1966: xxii). The shift in the division of labor between these two institutional facilities is further interesting because both have co-existed for the last 170 years. Hence, we witness here an invariant set of legal levels, the usage of which is beginning to change, so that as the one becomes more popular, the other declines (Collier, 1973: 51).

\section{The Setting}

The republic of Haiti is hardly industrialized and extremely rural. Its economy is heavily agrarian. A substantial proportion of the rural masses owns land, or has regular access to it, but the land is held in small plots and often without a clear title. Haitian peasants cultivate with three goals in mind: cash income from world market commodities (coffee, sisal); cash income from items produced for local sale

\footnotetext{
* Field Research was conducted in Haiti from March through June, 1972. The research and writing of this paper were supported by the Antilles research Program at Yale University. I wish to express my thanks to them and particularly to Professor Sidney W. Mintz for his invaluable encouragement and support throughout the period. I also wish to acknowledge my debt to Dr. and Mrs. L. Mellon, Tally Kauffmann and Dr. G. Berggren for their assistance during my stay in Haiti and to the following people who made comments on earlier drafts: R. L. Abel, J. F. Collier, J. Guben, H. F. P. Ietswaart, M. J. Lowy and S. W. Mintz.

1 Rural Haiti should not be treated as a unitary division. The section under discussion has been particularly exposed to social change and may not be an adequate representative of rural life in Haiti. It may however, represent the spearhead for social change, which will eventually occur in the more remote areas of Haiti.
} 
and consumption; and subsistence. However, crop choices and land use patterns rest fundamentally on a subsistence orientation ${ }^{2}$.

The population is largely illiterate and poor. Per capita annual income does not exceed $\$ 80$. Until recently, little attention was paid by the national government to the rural areas, and "(a)lthough some progress has been made, there is still a great lack of communications, health services, agricultural organization and schools" (Metraux, 1951: 2).

Field work was conducted in one of the rural sections of the commune of Verrete in the Artibonite Valley in west-central Haiti. The Section is conveniently located on the only major highway in the island. The Capital, Port-au-Prince and St. Marc - another major town - are easily accessible by local transportation. Transportation is available from the Section to the rural town of Verrete, which may also be reached by one hour's walk.

The Section is distinct from other rural areas in Haiti not only by its relative proximity to the Capital. The Artibonite Valley, where it is located, has been a center of development projects (most of which have been either abandoned or failed) between the forties and early fifties. As a result, its population has been more exposed to modern agricultural methods and techniques, in comparison with Haitian peasants elsewhere. Furthermore, the Section where field work was conducted has been the focus of foreign influence ever since the United States' occupation in 1915. Standard Fruit and Brown and Root had prosperous banana businesses in the region until they left Haiti in the early fifties. They introduced a modern conception of commercial agriculture, an extensive irrigation system and steady jobs and income. Since then, the Albert Schweitzer Hospital, which was established and is administered and financed by North Americans has operated in the area. The Hospital must have had considerable modernizing effect on the local inhabitants. It provides not only medical care, family planning and hygienic and nutritional education, but also agricultural assistance, modest road and water development and a considerable number of jobs.

The relative affluence of this area in Haiti has made it particularly attractive. Hence, a considerable portion of the population consists of migrants, who have been coming ever since the forties.

The Hospital has also attracted a nucleous of educated persons, employed by the Hospital and enjoying a high income in Haitian terms. (The Hospital is bound by Haitian labor legislation which provides for a minimum monthly wage of $\$ 31$. This should be contrasted with the general average of $\$ 80$ per caput income per annum, Moral, 1961: 320). The Hospital employees are not necessarily migrants. Some were born in the Section, or brought there at a very young age. The presence of the Hospital employees, as a relatively well-to-do group, has attracted of a growing number of people who furnish them with services, such as barbers, tailors, carpenters, room renters etc.

All the local inhabitants, regardless of occupation or income also maintain cultivated plots of land and livestock, when they can afford them.

Local religious persuasion ranges from Vodoun, the indigenous Haitian religion, to Catholicism (not necessarily mutually exclusive) and Protestantism. Missionary work has recently increased the number of converts to Protestantism ${ }^{3}$.

2 This summary is taken from Mintz, 1966: $x x v-x x x$.

3 Although no statistics on this point are available, it is interesting to note that many of the educated are practicing protestants who have denounced Vodoun. This factor may be linked to further social 
Education enjoys the highest priority. Parents will have their children walk to Verrete and back (two hours' walk) every day in order to have them educated in a school better than the local one. Aspirations for social mobility are also significant. It has been noted that urban merchant women aspired for service occupations for their children while rural marketing women (French-Fr. revendeuse) expected their children to continue their way of life. (Mintz, 1971: 259-266; Legermann, 1962: 148-149). In this area, parents work hard to provide not only for school but even for private tutorship after school, in order to enable their children to go to high school, and from there hopefully to the University. Having the child acquire a profession or occupation appears to be a common aspiration.

The area has no electricity (although poles for electric wires are installed) and no piped water. Despite the efforts to introduce modern techniques, already mentioned above, the land is still cultivated by the traditional hoe. The Section has a population of approximately 20,000 people and 54 "habitations" (Fr.) (An habitation is a vague and elastic term "denoting any area of land with which a single owner's name has remained associated" Metraux, 1951:9). It is the largest of 6 Sections forming the commune of Verrete. A modest government administration operates in the town of Verrete. This includes the military headquarters (which also constitutes the law enforcement machinery) and a tax collector, a sanitation officer, a Justice of the Peace, and the municipal authorities.

Every rural section is administered by a Chef de Section, a government appointee who performs all the immediate functions of public administration (Lahav, 1974: in press). Among his other functions, the Chef de Section manages disputes brought before him by the local inhabitants. When a dispute cannot be contained (for reasons which will be discussed later) it is referred to the Justice of the Peace at the nearby town (Fr. bourg Haitian Creole $=\mathrm{H}$. C. bouk). The Chef de Section and the Justice of the Peace are not the only remedy agents available in rural Haiti. Nonformal remedy agents, such as the elders of one's family; godparents; the Protestant (Fr. Pastéur), Catholic (Fr. Mon Père) or Vodoun (H. C. Bocor) priests may also be invoked for the purpose of settling a dispute among two or more parties. This paper, however, will focus only on the two formal remedy agents, who are officially appointed and recognized by the National government.

\section{The Chef de Section and the Justice of the Peace: a Comparative Analysis}

In the Section where field work was conducted, the Chef de Section constitutes the more traditional, familiar and popular remedy agent. Two notable exceptions are significant: 1) the upper strata of the Section, the wealthy, the educated and the hospital employees, who avoid resort to the Chef as much as possible, and 2) land disputes which are largely within the jurisdiction of the Justice of the Peace; there is a tendency to prefer the latter for debt disputes as well.

Following is a detailed comparison between the Chef de Section and the Justice of the Peace, which may provide a partial explanation of these findings.

Physical Setting: The Chef de Section's headquarters are located in a rented lakou (H.C. Fr. la cour. The lakou is "the central physical expression of rural social grouping in Haiti" Mintz, 1964: 258. The fact that an office in the lakou has

stratification since money not invested in ceremonial activities may be invested in acquisition of more land or for improvement of the standard of living (Wolf, 1966:16). 
been rented serves as another indicator of social change. Traditionally, the Chef's headquarters were located in the lakou where he lived). The lakou is inhabited by two families, both related to the Chef de Section. The Chef has a very small office, located in one of the two metal-roof huts in the lakou. It is furnished with 3 chairs and a desk improvised from a small wooden board placed on a cardboard box. The process of dispute management (usually referred to as process (Fr.) or jugement (Fr.), as well as performance of the Chef's other administrative functions take place in the open in the traditional tonel (H.C.): two benches placed under a lean-to plaited palm fronds. The Chef has a secretary (his son) and an aide (Fr. Police Bureau) (his uncle), in addition to a 49 man police force (Lahav, 1974: in press).

In contrast with the physical setting in which dispute mangement takes place in the Section, the judicial proceedings in town take place in a courthouse. The courthouse is an old and elegant (though neglected) one story wooden construction, with a spacious courtroom and a large porch. Inside the courtroom, a small wooden barrier separates the judge and his clerk from the audience. The judge uses a wide table, covered with papers and a small copper bell to help him to call the court to order. A second table, set on a raised platform, apparently has been designated for the usage of the judge, but it seems that it is not used by any of the court's personnel. A clerk (Fr. eggrifier), assisting the judge, has a separate table, next to the judge's. There are two Justices of the Peace in Verrete, a senior judge (Fr. juge titulaire) and a junior (Fr. juge suppliaire). To enforce its decisions, the court has at its command not only the Commandant (Fr.) - the chief of the military forces in the commune - but also the Chefs de Section, to whom he may issue direct orders. Since there is only one courtroom for the usage of two judges, the Justice of the Peace may also conduct judicial proceedings at his home. Adjudication at the judge's home is limited to civil cases alone, of both mandatory and voluntary (i. e., when the case falls under a higher jurisdiction) jurisdictions. The judge also accepts clients for professional consultation, even in cases where he may later preside as judge. An "ad hoc clerk" (Fr. eggrifièr ad hoc) is privately employed to assist the judge in handling the proceedings at his home.

Role Specialization: The Chef de Section has four years of elementary school education; his ability to read and write is rather limited. Most of the paper work is done by his secretary, who lacks a complete elementary school education, but possesses more experience in doing paper work. In response to inquiry, the Chef said that his superior in town taught him the job. Such training must have been of a general nature, referring mainly to the Chef's duties as prescribed by the rural code. His specialization stems to a large degree from experience. At the time when field work was conducted, the Chef had served only one year in his position. He was appointed to his post following the nation-wide bureaucratic organization which took place after the death of President François Duvalier. Previous to his appointment, the Chef served as a police agent (Fr. adjoint). A police agent is a subordinate of the Chef de Section, who has jurisdiction over a part (Fr. zone) of the Section. The agent manages minor disputes brought before him by the zone's inhabitants (Lahav, 1974: in press). The Chef, therefore, must have had experience in dispute settlement prior to his appointment to his present position. The Chef de Section is a person of considerable wealth (land, livestock) although he is by no means the wealthiest in the Section. Most importantly, he 
does not speak French, and thus is clearly a member of the rural masses rather than of the urban educated elite. His life style is not radically different from that of his constituency.

The Justice of the Peace 4 is a graduate of the University of Haiti School of Law in Port-au-Prince. He speaks fluent French as well as Creole. In the courthouse, he dresses in a dark suit, in contrast to the Chef's usually plain clothes. Like the Chef, he is on the Government's payroll, but it is common knowledge in Haiti that salaries are often delayed and are sometimes withheld due to mismanagement of the national budget. The Justice of the Peace is a native of Verrete, owns a house in the center of town, is known to be a member of the elite of the region and his life style seems to be higher than that of the Chef de Section.

Procedure: The process of dispute management before the Chef de Section has in informal character. It can occur any time of the day and every day of the week. Both the parties and the Chef sit in the tonèl (H.C.) Anyone interested in the process may join. The absence of social distance between the Chef and the other participants is rather conspicuous to the observer. The procèss (Fr.) is held in Creole and the parties are allowed to retell their versions to various groups within the audience as many times as they please. Anyone present may interrogate the parties and their witnesses and express an opinion. No counsel is employed, although people may bring along a relative or friend to speak for them and support their case. Witnesses are usually brought on the spot (in a rare case the Chef may go to the location of the dispute to collect evidence ) and all information is admissible as evidence. (A notable exception of this practice is the case of theft, where an eyewitness is required in order to substantiate such a charge). The process usually continues until a settlement is reached, or until it is clear that no settlement will be reached, when the parties may be sent to Verrete. The Chef de Section is more of a mediator than an adjudicator. He usually depends on the attitude of the audience in suggesting a cautious compromise and avoids placing exact blame on either side. His tactic is usually to let the parties exhaust themselves, telling and retelling their stories before suggesting a compromise; he thus ensures better psychological predisposition toward a settlement.

A dispute before the Justice of the Peace is usually heard in the courtroom. The litigants stand, facing the judge, their backs to the audience (thus unable to manipulate or rely on their peers). Of ten they are represented by counsel, primarily because of their awe before the State institutions and ignorance of their workings (an oft-quoted Haitian proverb says that "after God comes the State" implying the Government's omnipotence). The counsel available in the rural areas is usually a fondé de pouvoir (H.C.) - a man who has learned the law through experience, but has no academic qualifications and is not a member of the Haitian bar. When counsel is employed, the proceedings are held in French and translated to the parties by the clerk. There is no participation of the audience in the proceedings, and the power of the law is clearly felt by the judge's frequent reference to "what the law says". To the peasant who has spent most of his life in the rugged lakou, these proceedings seem as distant and alien as the proceedings before the Chef seem natural and familiar.

\footnotetext{
4 Interviews were conducted with only one of the two judges in Verrete.

5 A caveat in this regard is in order: I have never seen the judge or counsel to the parties use law books and his reference to the law may have been designed to satisfy me and may have not been used in by absence.
} 
Norms Applied: The main guideline underlying the Chef de Section's dispute settlement process is that conflicts are bad and that order should be maintained. Hence, the norms applied in his lakou are loose and flexible, with no reference either to precedent or to the official legal system and the rural code. The main principle openly used to arrive at a proposed resolution of the conflict is "what justice (H.C. la justice) demands". The proposed resolution, suggested by the Chef de Section, is frequently, but not always, in agreement with the participant's opinion of how the case should be resolved (i. e., the consensus emerging after the case had been thoroughly aired). "Justice" means taking into account the circumstances of the disputed activity; the age, sex, status and means of the parties involved; the goal of maintaining cohesion and good faith as well as the desirability of avoiding involvement with the authorities in town (which means a costlier process, a less friendly court and conceivably, more drastic results in terms of restitutive or punitive sanctions).

An illustration of this process is the case of Jules and Alphonse. Jules filed a complaint against Alphonse saying that the latter had threatened to chop off his head ${ }^{6}$. The incident occurred when both men were passing each other alongside the canal. Jules insisted that there had been no provocation on his part. Alphonse did not dispute the circumstances but claimed that he could not have possibly uttered a word since at that time he had a basket of corn on his head, his hat in his mouth and merchandise under his two arms. He demonstrated this vividly, borrowing items from the participants and arousing cheers and laughter. Both men were relatively well dressed, having both shoes and hats. After they had exhausted their anger by reciting their versions several times, the Chef intervened. Rather than searching for the facts he preached peace. People who fight, he said, were stupid (H.C. sot). People who were sent to Verrete were not serious but vagrants (Fr. vagabonds). If he sent them to Verrete, they would spend at least 15 days in prison and pay a fine, too. Therefore, he suggested, they should avoid fighting and make peace. Jules agreed, on the condition that Alphonse would repay him the complaint fee, 2 gourdes, which the latter promptly did. Alphonse's agreement to repay the fee constituted a tacit admission of complicity, although Jule's very quick agreement to drop the charge, also implied admission that the threat to his life was not very serious?. The dispute between the parties obviously had deep roots with which the Chef was either familiar or which he did not care to unravel. Neither did he care for finding out the truth about the alleged incident. What he wanted - and what the parties themselves apparently wanted - was to prevent an escalation of the conflict and to restore a certain degree of nonbelligerency between the parties.

The Justice of the Peace operates within the more rigid and formal framework of the legal system. He is bound not only by as modern and complex a body of codified law as can be found in any Western democracy, but also by knowledgeable lawyers. While these lawyers (H.C. fondé de pouvoir) are not members of the bar and have no formal legal education, they are known to exploit and manipulate the law of procedure to the maximum. As already mentioned earlier, most

6 The threat to chop off one's head with a machette is a common threat in Haiti (H. C. coupe tet ak machet) and should not be taken literally. In the entire history of the Section only one case of this actually happenning was mentioned, in which a robber trying to escape had cut off a man's head. The threat should be interpreted as a signal of a serious conflict between the parties which may end in violence.

7 I had later learnt that the two were neighbors who once shared close friendship. Jules was also the godfather to one of Alphonse's children. 
people hire a lawyer when involved in court proceedings. As far as I could tell (no systematic research on this point was done) there was no space in the court for the public's perception of "what justice demands" or for making any effort to maintain a modus vivendi. This impression may be supported by the judge's impersonal, somewhat arbitrary statement to the disputing parties that in their case the "Law says ...". However, since no lawbooks were present during the proceedings, one may also interpret the reference to the law as a means of pressuring the parties to reach an agreement, just as the Chef mentions the proceedings in town as a threat which might induce the parties to accept a compromise. Thus interpreted, the normative difference between the two legal levels may be that on the level of the Justice of the Peace, articulate norms are used whereas on the level of the Chef de Section moral rhetoric and pragmatic considerations are applied to achieve the same goal - a compromise agreeable to all parties.

Jurisdiction: Between March and June 1972, 49 case came before the Chef de Section. Of these, 18 cases - more than a third - were referred to the Justice of the Peace. (The actual number of cases adjudicated before the Chef must have been much higher. Cases may come before the Chef at any time of the day and my informants were unable to keep track of them; control over the cases sent to Verrete was much easier and more reliable since a copy of the process was kept in the Chef's office.)

A detailed analysis of the contents of the disputes is reserved for a later paper. In this paper, only some of the major findings which rest upon such analysis of the disputes, and are relevant to our discussion are presented. It is asserted that the dispute cases which were sent to the Justice of the Peace were graver (repeated thefts on a large scale; assault resulting in actual injury [bleeding] to the victim; debt of enormous proportions [210 gourdes]) than those resolved before the Chef (fights between wives sharing the same husband, first time theft by a boy or an old woman; disputes between father and son on the question as to woh would cultivate a certain plot; or cases of a patently rural character such as damage to crops by loose animals). This dichotomy between cases contained on the Section's level and those referred to the court suggests that the Chef de Section exercises jurisdiction over all small scale disputes of a distinct rural character, whether criminal or civil. Cases in which the facts are more serious are transferred to town. Such division of labor only partially conforms to the law. According to the rural code the Chef de Section has only to investigate the criminal violations of the law and submit the results of his investigation in writing (the document is called procèss verbal [Fr.] to the Commandant [Fr.]) - the chief of the military forces in town - who will submit the document to the court. Analysis of the cases suggests that the Chef refrains from submitting those cases which may be contained within the Section to other mechanisms of social control. It further indicates that those parties whose cases were solved before the Chef had an interest in continuing their relationship and wished to avoid escalation of the conflict.

This jurisdictional distinction between the Chef de Section and the Justice of the Peace reflects the basic pattern of the division of labor between the two institutions. However, this division of labor is not static and should not be rigidly conceived. The Chef de Section does refrain from transferring some very grave cases and refers to the Justice of the Peace some factually minor ones. When the parties involved are of high status or when public opinion demonstrates a strong 
opposition to having the parties sent to town (e. g., when the expected punishment in town is considered too severe) the case may be contained within the Section despite its grave criminal content. Conversely, when the parties expect to have a better outcome in town either because they have a patron who may better protect them there or because of their high status, they expect to receive more privileged treatment there, they may insist on being sent to town, in which case the Chef must comply, even if he thinks that the dispute should be resolved on the Section level.

The handling of civil disputes is by and large in accordance with the 1864 rural code, abolished in 1963 which provided for mediation of a dispute by the Chef de Section prior to its submission to the Justice of the Peace. However, as mentioned earlier, the Chef de Section's jurisdiction has been narrowed down in two significant areas: 1) the upper strata of the population bypass the Chef and address their legal problems directly to the Justice of the Peace. 2) land disputes, an important source of conflicts in the area, no longer come before the Chef de Section and instead are brought directly to the Justice of the Peace. It is the argument of this paper that these cuts in the Chef's jurisdiction signal a shift in the division of legal labor in the area.

Traditionally, the Chef de Section served as an indispensable link between the local inhabitants and the Government administration in town. All disputes, whether criminal or civil passed through him prior to being brought before the Justice of the Peace (Comhaire, 1955: 622-623). While the Chef still claims that no case can come before the Justice of the Peace unless it passes through his hands, it is obvious that this pattern is being increasingly modified. Today, the upper strata of the Section - the wealthy and the educated (mostly hospital employees) express open disdain for the process of dispute settlement as exercised by the Chef. Phrases like "he is a good fellow but cannot do anything" (i. e., unable to enforce a decision), "he is not serious", "he knows nothing", are common among these groups. It is worthwhile to reemphasize that the hospital employees are not necessarily in-migrants and that many of them were born in the region. Under normal circumstances, they would be expected to use the Chef de Section for the settlement of their disputes.

The wealthy who are usually involved in moneylending are concerned about his ineffectiveness - his tendency to grant repeated delays in the repayment of loans. The educated consider it beneath them to use this process, and would do so only where the odds weigh heavily in favor of adjudication before the Chef. An illustration is the common rural phenomenon of damage to crops caused by tresspassing animals (Metraux, 1951: 100-101). An educated person whose crops were damaged will prefer the traditional remedy agent - the Chef de Section to the Justice of the Peace. He will do so because the traditional and still highly binding norm in rural Haiti is that when crops are damaged by animals the proprietor should attempt to reach an agreement with the owner of the animal before involving the Chef or his agent in the dispute. When agreement is not reached, the Chef must be brought in to assess the damage before the case can go to town. Bypassing the Chef, i. e., insisting on transfer to town, and bringing in a higher authority would be considered a severe violation of the local norms, which in addition to increasing costs and wasting time may jeopardize the individual's position in the community. 
The lower strata, or the rooted peasants whose exposure to social changes has been minimal, still regard the Chef as omnipotent. Old peasants still tend to kneel before the Chef, calling him "papa" (H.C.) - the customary expression of submission - and pleading for mercy, even while presenting a civil dispute.

In addition to losing his position as a legitimate remedy agent of the upper strata, the Chef de Section is also losing his authority over land disputes. Traditionally, land disputes were settled by the Chef de Section and a council of the Section's elders (Comhaire, 1955:623; Metraux, 1951:16). Today, land disputes and particularly disputes concerning land ownership do not come before the Chef. At the same time, it is widely speculated that these compose the bulk of the cases adjudicated by the Justice of the Peace. This shift in the division of labor is significant since land is the most crucial factor in Haitian rural economic life, effectively determining one's very survival; its exclusion from the Chef's jurisdiction strongly undermines his authority. People in the Section tended to attribute this change to the Chef's ignorance of the land laws and the mechanisms of their enforcement (land registration, cadastral regulations). However, complicated land laws existed when the Chef was considered competent to adjudicate land disputes. The key factor in this change actually seems to be the scarcity of land. Land is scarce throughout rural Haiti due to a combination of population growth and the Haitian custom that all children, regardless of sex or legitimacy are entitled to inherit the father's or mother's land (Metraux, 1951:16-17, 22-23). In the region under discussion the land scarcity problem has been acutely aggravated by in-migration, which increased the demand for land.

Under these conditions of increasing scarcity of land and dependence on land for survival, the compromise oriented Chef de Section is no longer effective. The formal law may provide relief even where the community's norms of justice and proper behavior, as applied by the Chef de Section, dictate otherwise. An example is the case of illegitimate children, born after the father's legal marriage; they are not entitled to inherit land, but have been customarily taken into account when the father's land was parcelled. A legitimate child may seek to increase his share of land by disinheriting the illegitimate children in court. Furthermore, through clever manipulation of the laws of procedure, a case may be litigated for years, enabling a party to continue cultivation of the land, even when he knows that his case is not sound and will not stand in court. The scarcity of land is known to be unscrupulously exploited by lawyers, who solicit clients in the rural areas, promising favorable results through court proceedings. The exposure to western influence (the North Americans who do things differently) coupled with increasing outside pressure to purchase land (by in-migrants) must also have contributed to the replacement of the customary means of settling land disputes with the more formal institutions in town. In addition, the ever present possibility that someone will successfully challenge one's rights to the land through judicial proceedings has resulted in an aggravated sense of insecurity, leading to a growing recognition and usage of the formal means of contracting (having a contract made before the public notary in town) and judicial decision making.

It is also worth noting that the Chef de Section appears to be resigned to this reduction in his authority, and does not attempt to adjudicate land disputes. This acquiescence with the loss of land cases may be partially explained by the fact that the Chef is himself a peasant and owner of land, and like his fellow inhabi- 
tants has come to recognize the advantages in letting the state bureaucratic apparatus handle the land disputes. Another explanation lies in the fact that land disputes are potentially explosive and the Chef's involvement with them may jeopardize his position in the community. Having an outsider, like the Justice of the Peace make the painful decisions spares the Chef the risk of becoming the target for aggrieved individuals, who are involved in land disputes. The sheer volume of land disputes may also play a role in his resignation to his reduced authority. However, the Chef continues to provide contracts for land lease (H.C. papié) which do not have legal validity but provide some kind of assurance to the poor who cannot afford a public notary.

Costs: At the Chef's lakou the costs of litigation are usually measured in gourdes ( 1 gourde $=$ U.S. $\$ 0.20$ ). In the court, costs are measured in dollars. The complaint fee at the Chef's lakou is 2 gourdes. The most expensive type of litigation - an act de rejustrement (H.C. $)^{8}-$ costs an additional 7,50 gourdes. In three months, the highest sum decreed in litigation before the Chef was $\$ 5$ (( 25 gourdes) - as damages for a severe leg injury caused in a bicycle accident. The sum was not paid in my presence, and I could not ascertain whether it ever was paid in full.

All my informants indicated that the fees at the court are much higher. In criminal matters payment is also due the commandant, who has the local jail under his supervision. Even déplacement (H.C.) of the judge for constatation (H.C.), i. e., having the judge come to the location of the dispute, costs $\$ 5$ (25 gourdes) in comparison with the Chef's charge of $\$ 1$ (5 gourdes) for the same service. Costs of counsel and possibly higher bribes should also be included in a proceeding before the Justice of the Peace. In a case where a pig was stolen and sold in another section, a father and son were arrested. No evidence was found against the father, but he was detained for 2 days and paid $\$ 8$ (40 gourdes) for his release. The son, who insisted that he had bought the pig but could not name the vendor, was fined $\$ 15$ (75 gourdes) by the Justice of the Peace, and spent 11 days in jail.

Sanctions and Enforcement: In a proceeding before the Chef de Section, the results may be either resolution of the conflict or referral to the Justice of the Peace. It should be noted that referral to town is considered a punishment in itself, since it probably means greater costs and more severe sanctions, both restitutive and punitive (those who go to town pass a lot of misery [H.C. âpil mizé], I was told).

When a dispute case ends on the Chef de Section's level, the result may be either having the case dropped (due to unwillingness of the parties either to reach a compromise or to escalate the conflict by going to town); or a delay in the process (usually a debt case) or an accepted compromise. In criminal cases, the Chef may either reprimand the parties (usually in cases of a fight between husband and wife or two wives) or club or whip them (usually in cases of theft). Fines, in the form of an act de rejustrement (H.C.), are paid only in those rare cases where the parties convince the Chef not to send them to town, in spite of a grave offense. The Chef's power to ensure that an agreement between the parties is respected lies in the support of the community - moral and social pressure on the parties, and the parties' susceptibility to such pressure - and on his ability to send the

8 A solemn resolution of a conflict, put on paper and signed by both parties and the Chef. It is designed to avoid litigation in court where the sanctions awaiting the parties are considered too severe and undesirable. 
parties to the Justice of the Peace. His means of enforcement, therefore, are indirect and depend on the town's authority. The judge, on the other hand, has the commandant and the Chef himself, in his capacity as a police officer, to execute his decisions.

The preceding analysis explains why the Chef de Section is the preferred remedy agent. Personally, he belongs to the same reference group, sharing every aspect of local social life in terms of values, norms, common problems, language, education and background. In stark contrast to the Chef de Section, the Justice of the Peace belongs to an urban setting; by his academic education and mastery of French, he is associated with a radically different reference group. From the institutional viewpoint, the Chef de Section represents remedies with which the population is not only more familiar, but over which it has considerable control, and which are much cheaper and less time consuming than a proceeding before the Justice of the Peace. The preference for the Chef over the Justice of the Peace, therefore, lies in his effectiveness as a remedy agent which is more familiar, comfortable, cheaper and likely to end the conflict with a more agreeable result.

His effectiveness, however, depends on the conditions of his local constituency. They will recognize his authority only so long as they consider him to be the sole power broker between them and the government in town. In other words, a prevailing attitude of we (in the Section) vs. them (in town) is necessary for preference of the Chef de Section. His effectiveness also depends upon public opinion. We have seen that public opinion is instrumental for both the result of the dispute, and the subsequent enforcement of such result.

These factors seem to explain the shift in the division of legal labor between the Chef de Section and the Justice of the Peace. The increasing stratification and differentiation of this community has created groups of people who do not recognize the Chef as a legitimate power broker and identify more with the town administration. These groups will prefer the Justice of the Peace who is closer to them in background and education, despite the costs and time factors.

The scarcity of land, as well as the accelerated demand for it as a result of high inmigration, led to a refusal to accept compromises when land is involved. The community's norms are not as binding as they were in the past and the instinct to survive drives people to a seemingly ineffective remedy agent - the Justice of the Peace (more expensive, slower, negative reference group) in hopes of achieving ultimate retention of land. Compliance with the law as a means of assuring the security of one's rights seems to be only a byproduct of this process. Before the American Occupation, the process at the Chef's level was sufficient to provide security so that formal expression of it (H.C. papié) was not so crucial.

The handling of debts is another indicator of a beginning process of differentiation within the community. While the customary debt disputes involving market women (Fr. revendeuse) still come before the Chef, there is a growing dissatisfaction with his handling of them. The Chef tends to grant many delays in repayment because of his and the community's sympathy with the plight of the debtor and his policy of preventing escalation of the conflict by calling in the Justice of the Peace. The money lenders, some of whom are migrants, who have learnt to manipulate both the Chef and the Justice of the Peace, conduct a lucrative business of cash lending against high interest. They want their money back, so that it can "go on working", and therefore prefer the court, where they can get quick 
relief accompanied with effective police enforcement. The fact that more "modern" transactions of money lending such as the lending of cash to hospital employees never come before the Chef also indicate a decline in his authority in this area.

The division of labor between the Chef de Section and the Justice of the Peace, is not and probably has never been sharp and clear cut. However, a change in the usage patterns of the two institutions, in favor of the Justice of the Peace is currently taking place. This shift seems to constitute a phase in the evolution of legal organization from a less formal to a more formal institution. The following is an attempt to shed more light on this evolutionary process, putting it in an historical and theoretical framework.

\section{The Division of Legal Labor and Legal Evolution}

A situation where an indigenous remedy agent serves as "an important interface link in the communication network between the local . . and national segments" (Hunt and Hunt, 1969: 136) has been reported in other societies (Collier, 1974; Hunt and Hunt, 1969; Singer, 1974). Furthermore, both Collier and Singer have reported that competition between the local remedy agent and the national judicial system (the court) has so far resulted in favor of the former. In the case of Haiti, we have reported an opposite trend: a shift in favor of the Justice of the Peace. We shall return to this discrepancy after putting the Haitian case in its historical context.

An explanation of the present division of legal labor in rural Haiti must take into account the first decades of independence. At that time, much of the former public order, established by the French colonists, had been destroyed, and the ruling elite was looking for a political framework which would safeguard their aspirations for power, and at the same time reconstitute Haiti's economic prosperity.

The formal model for the construction of the Haitian republic has been the one with which its ruling elite identified most: the French model. Around 1825 an entire Haitian legal system was consolidated, based largely on the French system. However, this was not a case of straight importation of foreign law. The Haitian elite had both a genuine affinity with French culture and a clear sense of Haitian independence and consciousness. The Haitian legislature was mindful of the particular cultural milieu of Haiti and constructed its legal system accordingly. This is evident from the legislation of the rural code, an original Haitian contribution to the legal system, and one which had enormous political importance?

The rural code was the key to maintenance of political power, since the rural population constituted the overwhelming majority and was thus a potential menace to the ruling elite. Moreover, the code could be instrumental in revitalizing the Haitian economy, which depended directly on agriculture. Tight control of the liberated population and reinstitution of the plantation system could restore the old prosperity (Rotberg, 1971: 68).

Haitian political and legal organization make it clear that, from the start, the Haitian ruling elite opposed free access and complete exposure of the rural masses

9 For the history of the rural code see Lahav, 1974: in press. 
to the generalized and sophisticated legal system. The Chef de Section and his military superior in town were constructed as buffers between the population and the legal system proper, as symbolized by the Justice of the Peace. A political motive for this policy was undoubtedly the attempt to maintain effective military control over the rural masses. An effective Justice of the Peace, who might place the law above the army, could have undermined such goal.

This political motivation seems to explain the actual historic division of legal labor as distinguished from the statutory division. The complete control which was historically exercised by the Chef de Section over all criminal activity was not prescribed by law. The rural code authorized him only to investigate criminal activity and report it, a function more in line with the relationship between court and police, as known in the West. However, control of the criminal legal process is a major variable in effective control of the population ${ }^{10}$. The ruling elite was not prepared to allow a relatively independent body to intervene between the army and the rural population.

Also, the ruling elite may have been reluctant to allow free taste of the rule of law. Haitian law, based on a Western value system, is geared to protect the individual from arbitrary executive action. Implementation of this body of law could have convinced the Haitian peasant that he is indeed a citizen, not merely a farmer (Casimir, 1974: in press) and thus plant the seeds for questioning the legitimacy of Haitian despotism.

Another factor accounting for the division of legal labor may be the acute shortage of indigenous administrative experience or a pool of governmental or technical skills after the revolution which could allow for a reasonable administration of justice (Rotberg, 1971: 50). The Chef's effective screening of the disputes in his section reduced considerably the workload of the Justice of the Peace and the necessity to maintain an administrative body which would supervise enforcement of his decisions.

Another explanation is the social conditions of the rural masses at that time. Stricken first by the trauma of slavery and then by the chaotic years of war, the rural masses may not have been prepared for the complex modern legal system with which the educated elite easily identified. Talcott Parsons has observed that a generalized legal system with universalistic norms (such as the one consolidated in Haiti in 1825), represents "a distinctive new step, which more than the industrial revolution itself, ushered in the modern era of social evolution" (1965: 351). One may speculate that the Haitian elite was conscious of the gap between the social conditions of the rural masses and the sophisticated legal system and has therefore provided an intermediary agent: the Chef de Section, who would bridge this gap.

It is also likely that the rural masses favored a local institution like the Chef de Section, over the Justice of the Peace. One must remember that the Chef de Section has always been a wealthy and influential person, selected on this basis from the Section's populace.

A description of the traditional dispute settlement process has shown that the Chef shared adjudicatory powers with the section's elders (Comhaire, 1955:629) and that even today public opinion constitutes an important determinant of the

10 This may have been hinted at by Max Weber when he said that "one of the earliest creations of the princely power .... was a national penal law. Military considerations as well as general interest in 'law and order' demanded regulation in this ... sphere" Weber, 1954:258). 
settlement. These factors suggest that there had been popular sanctioning, or even assistance, in the consolidation of power over criminal disputes on the Section's level. A reason for such a trend may have been a desire to maintain internal control over an important mechanism of social control - the criminal legal system; this system seemed too crucial to be left in the hands of a negative reference group.

The marked preference for the Chef de Section by the local peasant population, for adjudication of their common daily disputes; their aversion to adjudication in town; and the Chef's own sense of responsibility toward his constituency, lend weight to this theory. The attempt to prevent criminal offenses from being reported in town, where the welfare of the parties or public opinion so require (within limits of his bureaucratic subordination to his military superior), and his reputation for delaying repayment of debts, illustrate this point.

The change in the traditional balance between the Chef de Section and the Justice of the Peace started with the American occupation in 1915. The Americans failed to understand the social functionality of the Chef, dismantled the institution and replaced it with a plain police force (Comhaire, 1955:622; Rotberg, 1971:120). Although empirical data on the consequences of this reform is scattered, one may assume that it broke the former contours of authority, and increased interaction of the Section's populace with the commune's authorities, including the Justice of the Peace. Attempts to restore the former structure have been made since Haiti regained political independence, but the likelihood of effective restoration of a former power structure is always doubtful. The concept of the Chef de Section as merely a policeman, once planted, could not be easily eradicated. The new rural code, enacted in 1963, shows that the ruling elite was reconciled to the idea of a Chef de Section who is merely Chief of Police.

The effectiveness of restoration is doubly questionable in the Section under discussion. Active American presence there was intensified after the American occupation was terminated. The Americans behaved in accordance with their perception of public order, treating the Chef as Chief of Police only and forwarding all disputes between them and the local population to the Justice of the Peace. "The Chef has no right to adjudicate disputes" was the answer to my inquiry why the Hospital does not use this service. Undoubtedly the population has been affected by this attitude, particularly those groups who came in close contact with the Americans. This may partially account for the disdain for the Chef de Section by the upper strata (another explanation being their alienation from the local reference group). The possibility that these groups signal the beginning of social stratification and differentiation suggest that the more differentiated the population becomes, the more the Chef will be reduced to performance of his police tasks, while the Justice of the Peace will extend his jurisdiction over disputes. Indeed, in the Commune under discussion, the workload of the Justice of the Peace has become so heavy that his territorial jurisdiction was cut from 6 to 5 sections, 1 section receiving its own Justice of the Peace.

The Chef's own conception of his role also indicates this change. Although he continues to settle disputes, he sees his major role as that of keeping order. His authority is also tightly curbed by his military superior in town and by the growing bureaucratization of government administration. One may also hypothesize that the growing awareness of the Chef of his role as a police officer and his consequent emphasis on order will crystallize the inevitable conflict between 
maintenance of order and the legality of conflict resolution (Skolnick, 1966:205), and thus further undermine his legitimacy as dispute settler.

This development is also in keeping with Wimberley's (1973) study of the evolution of elements of legal organization. Wimberley modified Schwartz and Miller's earlier study (1964), which suggested a scale of four elements of legal evolution: lack of legal organization; mediation; police; and counsel. The modification postulated a stage of legal evolution intermediary between mediation and police that of courts (p. 79). Wimberley also suggested a relationship between the development of a court-oriented police force and the strengthening of the court's authority. In the Haitian case, the rise of the Justice of the Peace coincided with the decline of the Chef de Section's role as a legitimate mediator and its transformation into a court directed police.

Finally, the creeping limitation of the Chef de Section's jurisdiction should be interpreted as an indicator of a fundamental change in the division of labor between him and the Justice of the Peace. Land, the most important factor in Haitian economic life, is already largely outside his jurisdiction. Only scattered cases of land lease, by the very poor (who probably realize his incompetence but cannot afford a public notary) come before him. It has been suggested that this may be explained by the scarcity and preciousness of land and the dissolution of the power of community elders to jointly enforce equitable land distribution. A preference for the law as applied by the Justice of the Peace is also detectable in the area of debt.

The Chef de Section is still the major dispute settler in the Section, but the division of legal labor is shifting; further social changes are likely to sharpen this process. With increasing social differentiation, one may predict that the jurisdiction of the Chef will shrink further; such jurisdiction may eventually include only minor disputes of patently rural and traditional character and parties, or matters which may not come before the Justice of the Peace because of illegality ${ }^{11}$. Thus, the Justice of the Peace may ultimately become the major dispute settler in the rural areas, further extending the effective application of the formal unitary legal system to the rural population.

As mentioned earlier, this conclusion contrasts with Collier's (1974: in press) findings in Zinacantan, where disputants failed "to use the national legal system despite efforts to promote economic or cultural integration". This discrepancy can be explained by, and sheds further light on, the particular Haitian social context. Unlike Zinacantan, there is no ethnic boundary between the rural masses and the national administration. Hence, the ethnic carrier, which plays an important role in Zinacantan, does not exist in the Haitian case. Also, the same formal legal system has been operative since the formation of the Haitian nation state and must have influenced the rural legal culture. Therefore, the resistance of the Haitian farmer to use the national legal system is likely to be far weaker than that of the Zinacanteco farmer. Furthermore, in Zinacantan the local leaders derive their political power from the people; they are thus in a much better position to manipulate the national legal system to their own advantage than the Chef de Section, who is a government appointee. The very close supervision over the Chef by the military. authorities in town (Lahav, 1974: in press) is also likely to undermine any efforts on his part to prevent usage of the Justice of the

11 For example, when the borlettes (H.C.) (gambling houses) were illegal under the late President Duvalier, matters concerning them were brought before the Chef de Section. 
Peace (unless the military would be interested in such prevention). It is also important to remember that so far there has been no Governmental effort to change usage patterns of remedy agents in rural Haiti (an effort which has taken place in Zinacantan). Since the Chef de Section is part of the national administration, it is very likely that his authority may be further reduced should the Government decide upon such policy. In sum, it is the different reality of the Haitian scene which explains why the Chef de Section is not likely to prevent increasing usage of the national judicial system, whereas in Zinacantan local leaders manage to prevent exactly such erosion of their jurisdiction.

\section{Conclusions}

This paper analyzed the two remedy agents available in rural Haiti, the Chef de Section and the Justice of the Peace. It showed that, by and large, the Chef de Section is the preferred remedy agent, but that social changes currently observable in Haiti are causing a shift in the traditional division of labor between the two.

As an institution, the Chef de Section has deep roots in the community; the process of dispute settlement before him is affected by public opinion; it is relatively inexpensive and prompt in resolving disputes. The Chef himself is a member of the community and shares their life style. On the other hand, the Justice of the Peace operates in an urban setting; the adjudicatory process before him is much more rigid and arbitrary; counsel is employed and a foreign language - French - is spoken; the process is expensive and relatively slow. The Justice of the Peace belongs to the middle class and is thus alienated from the peasant population.

It has also been shown that the ruling elite must have had vested interests in the traditional division of legal labor, partially because of the uneven pattern of development of Haitian society (elite vs. masses) and partially because of political reasons (maintaining complete military control over the rural areas).

The preferred status of the Chef de Section, being dependent upon a traditional peasant culture, is presently in jeopardy because this culture experiences social change. The Justice of the Peace now adjudicates the bulk of the more crucial and important cases. Members of the upper strata regard only the latter as the legitimate dispute settler. The process is only in its beginning phases, and granted a continuation of the painfully slow pace of social change in rural Haiti, will still continue for decades to come. But the change is already underway, and without a strong governmental intervention, is unlikely to be reversed. One would therefore expect more interaction between the Justice of the Peace and the peasant population at the expense of the Chef de Section, and consequently further intensification of the role of the modern unitary legal system in Haitian social life.

The distinctiveness of the Haitian case lies in the fact that its set of legal levels has been invariant for the last 170 years. Social differentiation and stratification, unrelated to Governmental policies, have led to a shift in the usage of legal levels, in favor of the national judicial system. 


\section{REFERENCES}

Casimir, Jean

Collier, Jane Fishburne

Comhaire, Jean L.

Galanter, Marc

Hunt, Eva and Robert Hunt

Jean-Jacques, Thalès

Lahav, Pnina

Legerman, Caroline

Metraux, Alfred

Mintz, Sidney W.

Moral, Paul

Parsons, Talcott

Rotberg, Robert I.

Schwartz, Richard D. and James C. Miller

Singer, Norman J.

Skolnick, Jerome H.

Weber, Max

Wimberley, Howard

Wolf, Eric R.
(1974), Social Classes And Ideology In 19th Century Haiti, 4 Occasional Papers: Antilles Research Program Yale University. In press.

(1973), Law and Social Change In Zinacantan. Stanford: University Press.

(1974), Political Leadership And Legal Change In Zinacantan, in Michael J. Lowy ed., Choice Making In The Law. In press.

(1955), The Haitian “Chef De Section”, 57 American Anthropologist 620.

(1972), The Aborted Restoration Of “Indigenous" Law In India, 14 Comparative Study of Social History 53.

(1969), The Role of Courts In Rural Mexico, in Phillip Bock ed., Peasants In The Modern World. Albuquerque: University of New Mexico Press.

(1933), Histoire Du Droit Haitien. Port-au-Prince. In French.

(1974), The Chef De Section: Structure and Functions Of Haiti's Basic Administrative Unit, 4 Occasional Papers, Antilles Research Program Yale University. In Press.

(1962), “Kin Groups In A Haitian Market” 62 Man 145.

(1951), Making A Living In The Marbial Valley (Haiti). UNESCO

Occasional Papers In Education 10.

(1964), The Employment Of Capital By Market Women In Haiti in Raymond Firth and B. S. Yamey, Eds., Capital, Saving And Credit In Peasant Societies. Chicago: Aldine Publishing Press.

(1966), Introduction To The Second Edition of James G. Leyburn: The Haitian People. New Haven: Yale University Press.

(1971), Men Women And Trade. 13 Comparative Studies In Society And History 247.

(1961), Le Paysan Haitien. Etude Sur La Vie Rurale En Haiti. Paris. In French.

(1964), Evolutionary Universals. 29 American Sociological Review 339.

(1971), Haiti - The Politics Of Squalor. Boston.

(1964), Legal Evolution And Societal Complexity. 70 American Journal of Sociology 159.

(1974), Legal Process As A Key To Legal Development in Michael J. Lowy ed., Choice Making In The Law. In press.

(1966), Justice Without Trial. New York: John Wiley \& Sons, Inc.

(1967 Rheinstein edition), Law In Economy And Society. Simon and Schuster.

(1973), Legal Evolution: One Further Step, 79 American Journal of Sociology 78 .

(1966), Peasants. Prentice Hall. 